\title{
Refined Construction of Financial Management System in Colleges and Universities
}

\author{
Yu Gu \\ Wuhan Textile University, Wuhan 430200, China \\ 83216542@qq.com
}

\begin{abstract}
Refined construction of financial management systems in colleges and universities is a necessary trend in modern management. It is also a necessary condition for financial management, which agrees with current higher education cause. Capital utilization efficiency should be regarded as the goal for management of colleges and universities. Financial management work should be implemented as an important task. Current situation of financial management at China colleges and universities is mainly analyzed during research process in the paper. Problems in system refined construction are proposed, thereby obtaining perfection countermeasures, and it is expected that the paper can play a reference role to some extent.
\end{abstract}

Keywords: Colleges and universities, financial management system, refined construction.

\section{Introduction}

The vast majority of financial management systems have more prominent extensive characteristics though there are sufficient financial management systems in China colleges and universities. It is practically required that colleges and universities financial management should be refined, refined construction process of financial management systems must be relied as a result, and the management means must be optimized through managing financial systems, dividing management levels and making clear responsibilities and permissions.

\section{Necessity of refined management of financial management systems in colleges and universities}

\subsection{Necessity for adapting to rapid development of market economy and higher education cause}

Education funds involved in the development process of China colleges and universities are mainly obtained from state funding for a long time. Schools formulate budgets according to the funding plan approved by superior departments, and expenditure is managed simply according to spending standards. However, it is obvious that the state funding could not meet the needs of expenditure under current background of rapid development of socialist market economy if colleges and universities rely on state funding simply. The consciousness of operating schools independently should be improved. Diversified channels should be utilized as far as possible for raising funds, thereby further realizing the regenerative capacity of existing funds. The original extensive accounting work system already can't agree with the demand of market economy and higher education cause. Therefore, the accounting work should not merely lie in original function on the one hand, optimized allocation of capital in school internal management should be further considered on the other hand.

\subsection{Necessity for adapting to reform development in colleges and universities}

In recent years, financial work reform in colleges and universities is also ascended to a new level under driving role of education teaching reform in the colleges and universities. Colleges and universities should realize the opportunities and challenges brought by current reform on the one hand, management personnel of colleges and universities should consider how to accelerate the development pace aiming at new form on the other hand, thereby adapting to the reform demand in 
colleges and universities and finally realizing the transition from extensive management to refined management.

\section{Problems of financial management system in colleges and universities}

\subsection{Single funding channel}

First of all, funds of public colleges and universities rely on state funding excessively. Current public schools still depend on state funding mainly since the schools are affected by higher education financial investment systems for long time. Especially some deployment colleges and universities have relatively high funding standards compared with other schools. In addition, funding accounts for higher proportion in total funds. School leaders pay less attention to fund raising.

Secondly, higher education in China enjoys relatively small society fund donation compared with foreign countries, therefore the gap is very big. Education teaching activities in western countries depend on donation income basically for higher proportion with the United States as a representative. Universities in the United States have a long history of accepting social donation. Own characteristics can be combined for formulating diversified and targeted donation measures aiming at different colleges and universities in order to maximally meet the requirements of donors mainly, thereby obtaining more social donation.

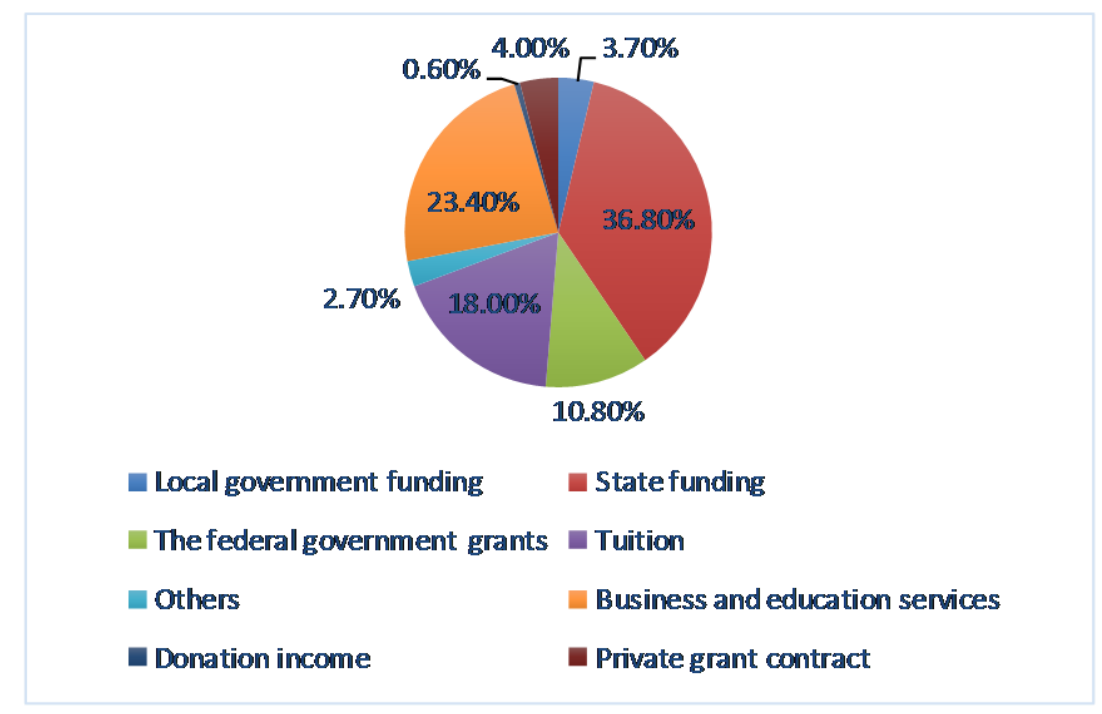

Fig. 1 Regular fund total revenue source of public colleges and universities in the United States

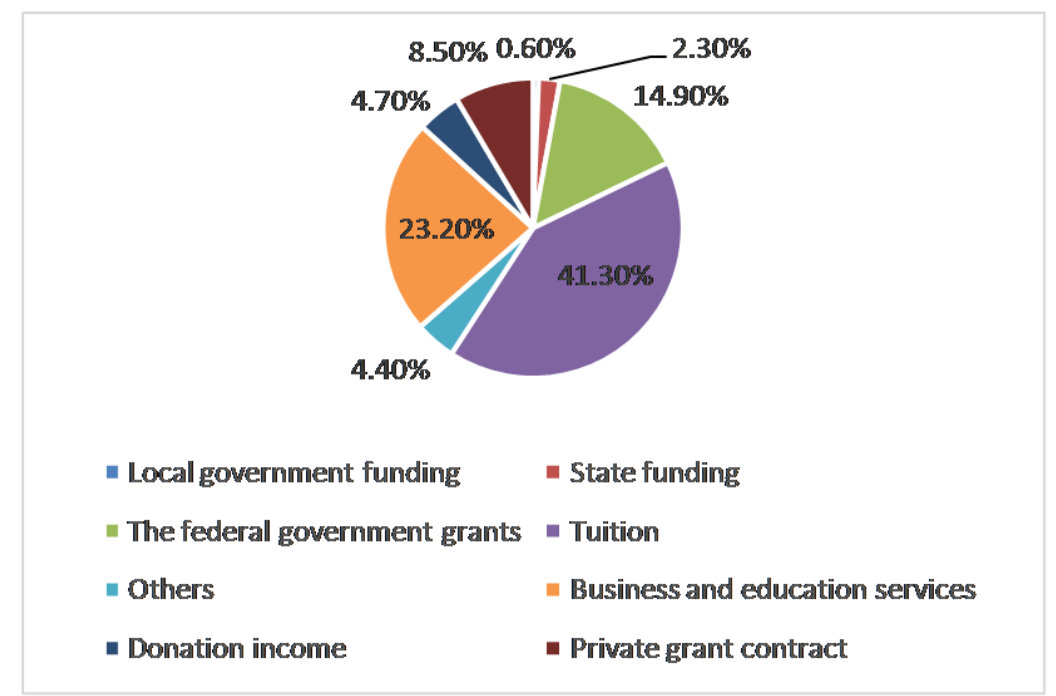

Fig. 2 Regular fund total revenue source of private colleges and universities in the United States

Donation form shows that donation of private personnel or private enterprises is mainly involved in foreign countries, and the donation modes include cash, securities, property ownership, etc. The 
situation of domestic colleges and universities shows that the condition of accepting social donation can not be actually improved easily within short term. In addition, certain conditions are required for establishing education funds. The procedures are more complicated. Therefore, positive donation environment has not been realized.

\subsection{Deficient education cost accounting system}

Budget accounting should be regarded as a foundational task in order to perfect accounting systems in universities and colleges and strengthen financial system in universities and colleges from the macroscopic level. 'Cash basis' is widely accepted in current accounting process in colleges and universities. Actual receipt and payment practice of cash should be always regarded as a marker under the system, thereby reflecting and supervising capital operational status. Accounting foundation work can not meet the requirement when colleges and universities account education cost due to deficient education cost accounting system. In addition, colleges and universities have higher charge and student can not pay tuition easily in recent years, and it is difficult to obtain effective achievements if financial and accounting management systems can not be innovated fundamentally, and accounting subjects can not be set according to talent training plan in colleges and universities. It is originally required that special fund should be used for special purpose in the field of special management of project funds, thereby the supporting facilities should meet basic needs, thereby ensuring that the fund can not be used for other purpose as far as possible, and realizing benefits maximally. However, there are still problems in the aspects of resources allocation after corresponding project fund is obtained in colleges and universities. There are even phenomena of purchasing equipment repeatedly, dividing and occupying resources, etc.

In addition, financial departments budget merely for budget, and grass-roots departments make budget for obtaining money due to limitations in the aspect of macro-system reform. Negative phenomena are common. Financial supervision also has certain limitations itself since grass-roots departments are lack of initiative and enthusiasm cost control. Different departments are controlled by different school leaders due to limitation of internal management systems in colleges and universities. Therefore, there are more complex relationships; the originally defective systems do not have response constraining force once complicated personnel problems are involved.

\subsection{Separated asset ownership and management use right}

The distribution condition shows that internal assets of colleges and universities mainly involve teaching, teaching assistance, organ, logistics, industry, etc. The use nature shows that operational assets and non-operating assets are mainly involved. Internal management departments of colleges and universities should be responsible for party committee leaders from the microscopic perspective according to right patterns of position appointment. Since internal property rights are not divided clearly, there are always loose states in management; property ownership is separated from management right. Inconsistency between account book and actual situation is displayed mainly in the aspect of assets management, and there still loss and waste. Studies of previous scholars show that 'collective private ownership', 'private collective ownership' and similar concepts have been stressed to certain extent. The public ownership implemented in China for long term is analyzed more profoundly according to 'collective private ownership', some defects about public ownership are summarized, which are mainly embodied in separation of ownership and use right. Such rigid public ownership has direct influence on state-owned assets in public colleges and universities.

\subsection{Unreasonable personnel structure and redundant personnel accumulation}

Institutions established in colleges and universities also should draw close to the government in order to agree with government administrative management. Administrative management personnel can not be simplified under such a macroscopic background, and administerization and stratification of management in colleges and universities become very prominent. Teaching affiliated departments can not control institution personnel registration, which is related to library, reference room, laboratory and other departments. These departments already suffer from redundant personnel accumulation. In recent years, colleges and universities have realized optimized management from the perspective of policy in the process of talent introduction. However, non-teaching personnel are 
more and more in colleges and universities, especially in logistics management. Personnel can not flow and divided. Some colleges and universities even believe that schools must keep stable and construct harmonious campus for development. Any reform should not lead to instability in personnel teams.

\section{Strategies of financial management system refined construction in colleges and universities}

\subsection{Reform management system}

Firstly, the autonomy of colleges and universities should be defined and implemented. Colleges and universities face obvious market pressure currently. Own features must be kept under current macro environment in order to occupy certain space in the fierce market competition. Objectively speaking, colleges and universities have higher degree of marketization, more autonomy should be grasped by them, thereby facing opportunities and risks better. Governments, colleges and universities should realize 'unity between policy and education', thereby converting government functions maximally. Current colleges and universities should respect the rule of market economy as previous state-owned enterprises. Governments should guide operations of colleges and universities under the limitation of law. Secondly, school running autonomy in colleges and universities should be defined without random financial executive orders. Practical experience of the developed countries can be adopted as reference.

Meanwhile, many funds are distributed according to market mode besides allocation system according to student quota. Firstly, corresponding pricing autonomy can be suitably given to colleges and universities in the aspect of examination and approval of charging standards, especially charge pricing right for training various graduates except general technical colleges and undergraduate schools with lower social influence. Such pricing autonomy is more universal in foreign universities. Secondly, the strengthening of charging tuition in colleges and universities should be canceled in the process of managing tuition. Such surface systems actually belong to government management on income of colleges and universities. In fact, colleges and universities are forcibly included into government fiscal sequence, thereby the regulation and control ability of colleges and universities for capital is weakened objectively, and capital turnover links are also increased, thereby improving the financial cost effectively.

\subsection{Perfection of financial management system implementation mechanism in colleges and universities}

Operation of each system involves funding support more or less from the horizontal perspective. In addition, a series of financial systems not only include budget management systems and accounting systems, but also are involved in asset management systems, cost management systems, etc. It is inevitable to process financial relationships in the process of coordination with other departments. Therefore, the coordination among school-level leaders is especially important. Clique interests should be avoided macroscopically from the perspective of schools in the process of system design.

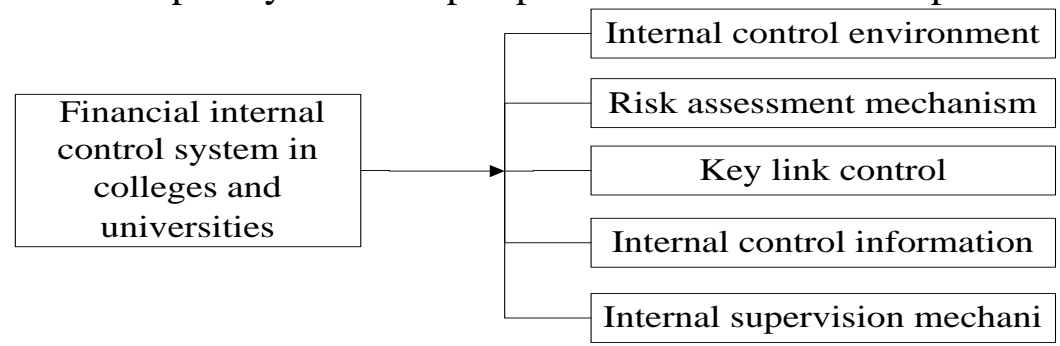

Fig. 3 Work system of financial management in colleges and universities

Coordination among systems should be focused during system design. Personnel salary management system should be effectively linked with cost accounting systems, fund performance appraisal systems and other aspects. Actual effect can be achieved as a result. All systems should be closely linked for exerting the role of system actually, thereby enhancing durability of finance and avoiding various risks. 


\subsection{System guarantee of realizing efficient financial sustainability}

Accounting basis in colleges and universities should be transferred from cash basis system gradually to accrual accounting system. Accounting systems and accounting report systems should be established again. Education cost in colleges and universities should be divided from a macro point of view. It is related to personnel expenditure, teaching business expenditure, public expenditure, asset expenditure, etc. on the one hand, these expenditures also can basically cover all elements in education cost of colleges and universities. Existing accounting work is supported by technology; the system design must be more detailed and scientific. Existing financial accounting systems in colleges and universities must be reformed according to requirements at both micro and macro levels. It is also an important link to realize education cost control in China colleges and universities.

\subsection{Establishment of sustainable financing systems in colleges and universities}

It is obvious that construction of foreign countries in the field has achieved more mature development achievements in the process of analysis on foreign universities. Cambridge University is adopted as an example. Cambridge University has no bank loan till present. Finance department should propose suggestions to school financial committee if there is a loan. Then, the finance committee can propose suggestions to the university council with plan and resources committee. Then, the university council can make a resolution. Finally, the suggestions should be approved by university appraisal team. Therefore, establishment and perfection of sustainable financing system in colleges and universities can assist the colleges and universities to create effective financing system environment and alleviate financial pressure.

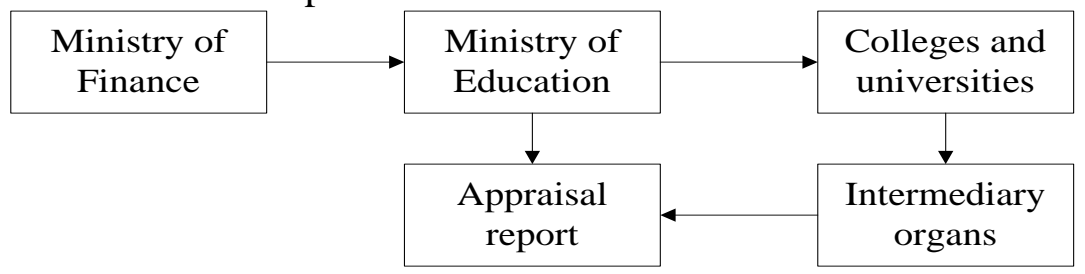

Fig. 4 Special fund declaration process of colleges and universities

\section{Conclusion}

People attach attention to improvement and development of modern university systems under current background of higher education globalization. Management personnel of China colleges and universities should update development idea timely, and strengthen perfection of financial management and strengthen refined construction from perspective of systems. Therefore, efficient system guarantee can be provided for sustainable development of higher education, and the promise of social stability can be brought to us

\section{References}

[1] J. van der Geer, J.A.J. Hanraads, R.A. Lupton, The art of writing a scientific article, J. Sci. Commun. 163 (2000) 51-59.

Reference to a book:

[2] W. Strunk Jr., E.B. White, The Elements of Style, third ed., Macmillan, New York, 1979. Reference to a chapter in an edited book:

[3] G.R. Mettam, L.B. Adams, How to prepare an electronic version of your article, in: B.S. Jones, R.Z. Smith (Eds.), Introduction to the Electronic Age, E-Publishing Inc., New York, 1999, pp. 281-304.

[4] R.J. Ong, J.T. Dawley and P.G. Clem: submitted to Journal of Materials Research (2003)

[5] P.G. Clem, M. Rodriguez, J.A. Voigt and C.S. Ashley, U.S. Patent 6,231,666. (2001)

[6] Information on http://www.weld.labs.gov.cn

[7] Chen Ranran. On financial management system refined construction in colleges and universities [J]. Modern Marketing, 2013 (1):124-125. 
[8] Li Hua, Zeng Ping. Analysis on establishment of logistics financial management modern enterprise system mode in colleges and universities analysis. Journal of Sichuan Vocational and Technical College, 2013, 23 (6): 91-93.

[9] Xie Zhihong. Influence of national treasury centralized payment system on financial management in colleges and universities. Higher Building Education, 2009, 18 (3): 153-157.

[10] Du Yonghong, Ding Yufang, Gao Hong, etc. Research on financial refined management problems in national colleges and universities during new era. Journal of Northwest University for Nationalities: philosophy and social sciences, 2014 (1): 161-164.

[11] Zhao Shanqing. Review on detailed study of financial budget in colleges and universities. Communication of Finance and Accounting, 2013 (23): 47-49.

[12] Guangming Daily. Headmaster talk of financial management in colleges and universities. Guangming Daily, 2015.

[13] Huang Xia. Discussion on refined financial management in colleges and universities based on the system point of view. Hong Kong and Macao Economy, 2014 (2): 54-54. 